\title{
Pelvic Arteries in Macacus Cyclopsis
}

\author{
Part 1. The Common Iliac Artery and the \\ External Iliac Artery
}

by

\begin{abstract}
Junji Fujita
First Department of Anatomy, Faculty of Medicine, Nagasaki University

(Under the supervision of Prof. Jun-ichiros a toh)
\end{abstract}

\section{Introduction}

Although there are many reports on the results of anatomical studies of the arteries in the pelvic region of primates, only a few cases have been used in most of these investigations, and thus it is practically impossible to discuss the normal type (standard type) of the species from these findings. Because of this situation, a study has been in progress in this department under the supervision of Professor $\mathrm{S}$ ato $\mathrm{h}$ in which a large number of Formosan monkey are investigated and the findings are considered from the statistical aspect for the determination of the standard type of the various characteristics of the different systems and organs. This paper, which deals with one part of this study, describes the state of origin, branches, course, distribution, etc., of the arteries which supply the inner aspect of the pelvis and the external genital region and their relation to the nerves. In addition, the findings were compared with previous reports on primates.

For the purpose of this report, the arteries were classified into the common iliac artery, external iliac artery and the internal iliac artery. In this part of the report, only the common iliac artery and the external iliac artery and their branches will be discussed.

\section{Material and Method}

The material consisted of 50 bodies ( 23 male, 27 female) selected at random from among the Macacus cyclopsis which had been collected by Professor Satoh and preserved in this department. All 
of these animals, after capture and strangulation, had been fixed immediately by the injection of $10 \%$ formalin solution into the femoral artery, and in some cases dye had also been injected into the blood vessels. These animals were preserved in jars of $10 \%$ formalin solution.

Gross anatomical inspection was done by the use of a dissecting knife and tweezers, and whenever necessary a binocular loupe was used. To observe the smaller branches, injections of the dye solution described below were given to cases that had not had previous dye injection. The dye solution that had been injected was prepared by the following method. First, white of egg was cut into very small pieces and filtered through filter paper. This filtrate was use to prepare liquid ink from a red ink stick. This solution penetrates further into the small branches than laquer, etc.

\section{Findings and Consideration}

\section{A. iliaca communis}

At about the level of the 6th lumbar vertebra, the abdominal aorta gives off the common iliac arteries to each side which supply the pelvic region and lower extremities. The continuation of the main trunk becomes the caudal artery.

The common iliac artery descends obliquely lateralward on the lateral wall of the pelvis along the medial edge of the iliopsoas and divides usually at the level of the promontorium on the anterior surface of the sacroiliac joint into the internal and external iliac arteries which are of about equal size.

The left and right common iliac veins, which accompany the common iliac arteries on each side, unite on the dorsal side of the right common iliac artery to form the vena cava inferior.

During its course, the iliolumbar artery is given off in the majority of cases.

There are seven lumbar vertebrae in Macacus cyclopsis and the location of the origin of the common iliac arteries on each side was measured by projecting this location upon the vertebra. In the majority of cases, the origin is at the level of the 6 th lumbar vertebra $(80 \%)$; most often at the upper third or middle third of this vertebra. There is a tendency for the level of origin to be higher in female than in male (Table 1). 
Table 1. Level of bifurcation of the A. iliaca communis.

\begin{tabular}{|c|c|c|c|c|c|c|c|}
\hline & & \multicolumn{3}{|c|}{ Fujita (Macacus cyclop.) } & \multicolumn{2}{|c|}{ Usui } & \multirow{2}{*}{$\begin{array}{c}\text { Imai } \\
\text { Macacus } \\
\text { rhesus (우의 }\end{array}$} \\
\hline & & $\hat{\delta}$ & 우 & $\hat{\delta}+$ 우 & $\begin{array}{l}\text { Macacus } \\
\text { rhesus ( } \hat{0})\end{array}$ & $\begin{array}{l}\text { Cercopith } \\
\text { ecus }(\hat{\delta})\end{array}$ & \\
\hline \multicolumn{2}{|c|}{ Vth-intervertebral disc } & 1 & 3 & $4(8.0 \%)$ & $1(12.5 \%)$ & & \multirow{4}{*}{$9(90.0 \%)$} \\
\hline \multirow{3}{*}{$\begin{array}{c}\text { VIth-vertebral } \\
\text { body }\end{array}$} & upper & 9 & 9 & $18(36.0 \%)$ & & & \\
\hline & middle & 6 & 11 & $17(34.0 \%)$ & $2(25.0 \%)$ & & \\
\hline & under & 2 & 3 & $5(10.0 \%)$ & $4(50.0 \%)$ & & \\
\hline \multicolumn{2}{|c|}{ VIth-intervertebral disc } & 3 & 1 & $4(8.0 \%)$ & & $3(100.0 \%)$ & \\
\hline \multirow{3}{*}{$\begin{array}{c}\text { VIIth-vertebral } \\
\text { body }\end{array}$} & upper & 2 & & $2(4.0 \%)$ & & & \multirow{3}{*}{$1(10.0 \%)$} \\
\hline & middle & & & & & & \\
\hline & under & & & & & & \\
\hline \multicolumn{2}{|c|}{ promontory of sacrum } & & & & $1(12.5 \%)$ & & \\
\hline \multicolumn{2}{|l|}{ total } & 23 & 27 & 50 & 8 & 3 & 10 \\
\hline
\end{tabular}

In general, the level of origin of the common iliac arteries of each side in primates is said to be usually at the level of the last or second from last lumbar vertebra (P o p o w s k , Li n e back, $\mathrm{Thi}$ ie, etc.). Even in the reports by $\mathrm{Imai}$ and $U \mathrm{sui}$, who have examined a comparatively large number of cases, the level of origin most of ten corresponds to the 6th lumbar vertebra in Macacus rhesus and the intervertebral disk of the 6 th lumbar vertebra in Cercopithecus aethiops. These findings do not differ much from my observations on Macacus cyclopsis, but there is a tendency for the origin in my cases of Macacus cyclopsis to be slightly higher than in their studies. Usui has reported one case of Macacus rhesus (male) in which the separation occurred at the level of the promontorium, but such low separation was seen in none of my Macacus cyclopsis.

In man, this artery has been reported to arise most frequently at the level of the fourth lumbar vertebra or the intervertebral disk of the fourth lumbar vertebra in both Japanese adults (A d a c hi, Tsukamoto, Yasukawa) and Japanese fetus (Hoshiai, $\mathrm{Sh}$ imada). Since there are five lumbar vertebrae in man, however, the location of separation is similar to other primates in that the separation occurs at the level of the second from last lumbar vertebra. 


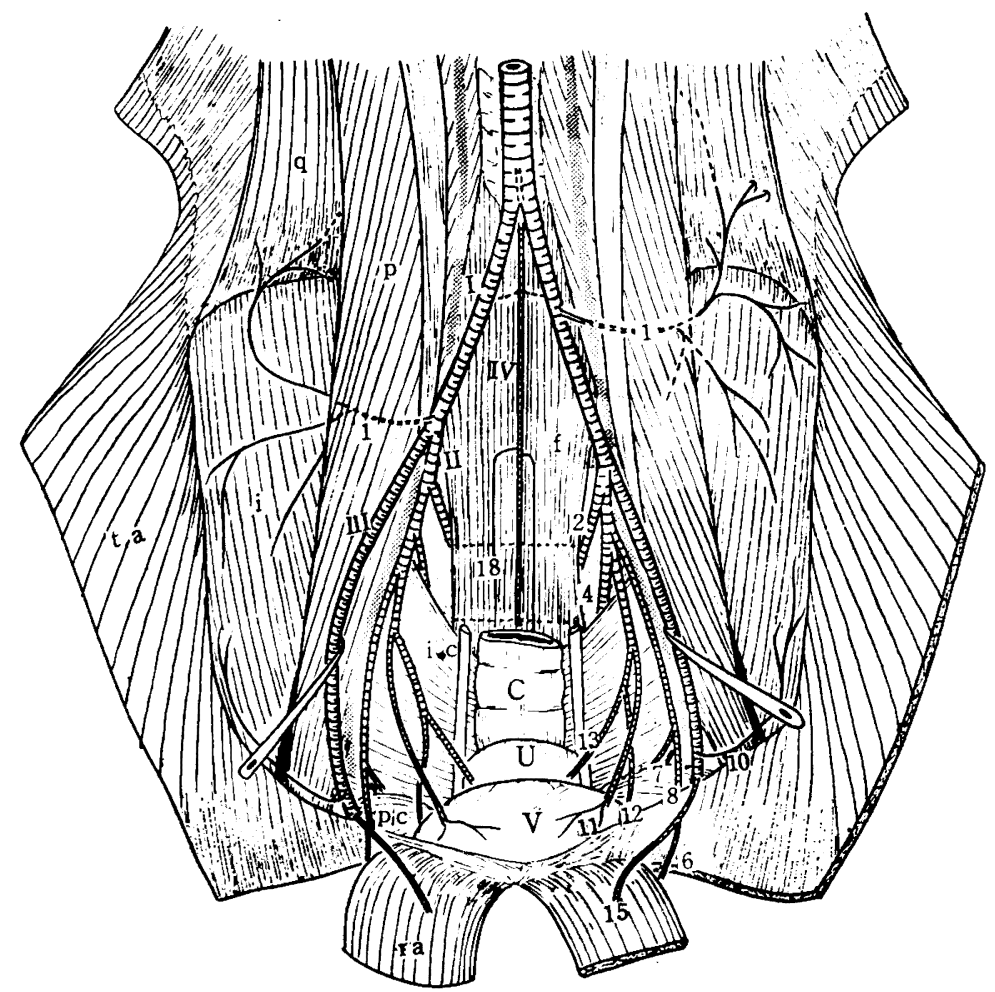

Fig. 1. An anterior view of the pelvic arteries.

I a. iliaca communis

II a. iliaca interna

III a. iliaca externa

IV a. caudalis media

1 a. iliolumbalis

2 a. glutea superior

4 a. pudenda interna

6 a. pudenda externa profundus

7 a. obturatoria

8 a. circumflexa femoris medialis

10 a. circumflexa ilium profundus

11 a. vesicalis superior

12 a. vesicalis inferior

13 a. uterina
15 a. epigastrica inferior
18 a. caudalis lateralis
a m. adductor longus
f m. flexor caudae longus
i m. iliacus
ic m. iliocaudalis
pc m. pubocaudalis
ra m. rectus abdominis
ta m. transversus abdominis
C colon
U uterus
V vesica urinalis

\section{(1) A. iliolumbalis}

The common iliac artery in most Macacus cyclopsis, unlike the condition in man, gives off the iliolumbar artery. The iliolumbar artery usually arises as a single vessel (96\%), most of ten from the common iliac artery $(61.4 \%)$ and occasionally from the lateral sur- 


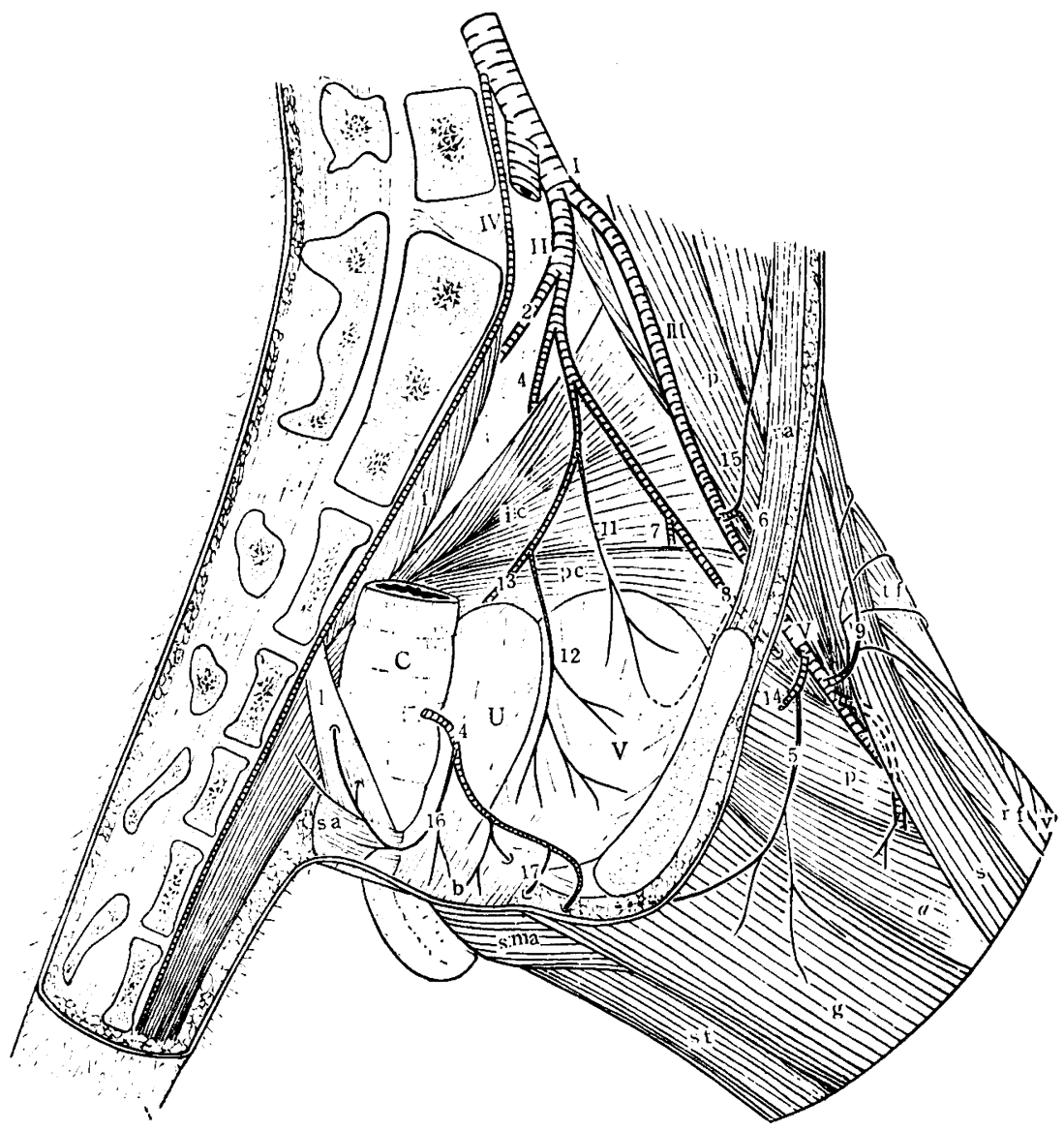

Fig. 2. The arteries in the left pelvic floor of a female.

I a. iliaca communis

II a. iliaca interna

III a. iliaca externa

IV a. caudalis media

$\mathrm{V}$ a. femoralis

2 a. glutea superior

4 a. pudenda interna

5 a. pudenda externa superficialis

6 a. pudenda externa profundus

7 a. obturatoria

8 a. circumflexa femoris medialis

9 a. circumflexa ilium superficialis

11 a. vesicalis superior

12 a. vesicalis inferior

13 a. uterina

14 a. epigastrica superficialis

15 a. epigastrica inferior

16 a. haemorrhoidalis inferior

17 aa. perineales a m. adductor longus

b $m$. bulbocavernosus

$f$ m. flexor caudae longus

g m. gracilis

i m. iliacus

ic m. iliocaudalis

$1 \mathrm{~m}$. levator ani

p m. psoas major

pc m. pubo caudalis

ra m. rectus abdominis

$r f \mathrm{~m}$. rectus femoris

$\mathrm{s}$ m. sartorius

sa m. sphincter ani

sma m. semimembranosus accessorius

st $m$. semitendinosus

tf $m$. tensor fasciae latae

$\mathrm{v} \mathrm{m}$. vastus lateralis

C Colon

U Uterus

$\mathrm{V}$ Vesica urinalis 
these arteries. In such cases, it passes in front of the common iliac vein to the dorsal side from where it takes the above course $(5.2 \%)$.

(i) Ramus lumbalis

The lumbar branch supplies the quadratus lumborum, and the obliquus abdominis internus and externus. In the majority of cases, there is anastomosis with other arteries (47\%). Most frequently such anastomosis is with the 12 th intercostal artery $(37 \%)$. In other cases, there may be union with the superior gluteal artery, superficial circumflex iliac artery, deep circumflex iliac artery, etc. (Table 3).

Table 3. Anastomosis between the R. lumbalis (A. iliolumbalis) and other arteries.

\begin{tabular}{|c|c|c|c|c|c|c|c|}
\hline & \multicolumn{3}{|c|}{$\mathbf{r}$} & \multicolumn{3}{|c|}{1} & \multirow{2}{*}{$\begin{array}{c}\text { total } \\
(98)\end{array}$} \\
\hline & (23) & 울 & $\hat{0}+$ + & $\begin{array}{c}\hat{\delta} \\
(23)\end{array}$ & 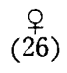 & $\begin{array}{c}\hat{0}+\text { ㅇ } \\
(49)\end{array}$ & \\
\hline XIIth-A. intercostalis & 9 & 9 & 18 & 9 & 10 & $19(38.7 \%)$ & $37(37.7 \%)$ \\
\hline $\begin{array}{l}\text { XIIth-A. intercost., A. glut. } \\
\text { sup., A. cir. ili. supf. }\end{array}$ & & 1 & 1 & & & & $1(1.0 \%)$ \\
\hline $\begin{array}{l}\text { XIIth-A. intercost., A. cir. } \\
\text { ili. supf. }\end{array}$ & & & & & 1 & $1(2.0 \%)$ & $1(1.0 \%)$ \\
\hline $\begin{array}{l}\text { XIIth-A. intercost., A. glut. } \\
\text { sup. }\end{array}$ & & & & 1 & & $1(2.0 \%)$ & $1(1.0 \%)$ \\
\hline $\begin{array}{l}\text { A. circumflexa ilium } \\
\text { superficialis }\end{array}$ & & 2 & 2 & & 1 & $1(2.0 \%)$ & $3(3.0 \%)$ \\
\hline A. glutea superior & 1 & & 1 & & & & $1(1.0 \%)$ \\
\hline total & 10 & 12 & 22 & 10 & 12 & $22(44.9 \%)$ & $44(44.8 \%)$ \\
\hline
\end{tabular}

(ii) Ramus iliacus

The iliac branch, which supplies the iliacus muscle, frequently anastomoses with other arteries (81\%). Within the transversus abdominis, it may unite with the deep circumflex iliac artery (26\%) and in the subcutaneous region of the abdominal wall there may be anastomoses with the superficial circumflex iliac artery (25\%). In addition, at the lateral edge of the ilium, there may be union with the lateral circumflex femoral artery or the superior gluteal artery (Table 4). There was a case in which the lumbar and iliac branches each 
Table 4. Anastomosis between the R. iliacus (A. iliolumbalis) and other arteries.

\begin{tabular}{|c|c|c|c|c|c|c|c|}
\hline & \multicolumn{3}{|c|}{$r$} & \multicolumn{3}{|c|}{1} & \multirow{2}{*}{$\begin{array}{l}\text { total } \\
(98)\end{array}$} \\
\hline & $\begin{array}{c}\hat{\delta} \\
(23)\end{array}$ & $\begin{array}{c}\text { ㅇ } \\
(26)\end{array}$ & $\begin{array}{c}\hat{\delta}+o \\
(49)\end{array}$ & $\begin{array}{l}\hat{0} \\
(23)\end{array}$ & $\begin{array}{c}9 \\
(26)\end{array}$ & $\begin{array}{c}\hat{\delta}+\phi \\
(49)^{+}\end{array}$ & \\
\hline $\begin{array}{l}\text { A. circumflexa ilium } \\
\text { profunda }\end{array}$ & 4 & 8 & $12(24.5 \%)$ & 7 & 7 & $14(28.5 \%)$ & $26(26.5 \%)$ \\
\hline $\begin{array}{l}\text { A. circumflexa ilium } \\
\text { superficialis }\end{array}$ & 8 & 3 & $11(22.4 \%)$ & 6 & 8 & $14(28.5 \%)$ & $25(25.5 \%)$ \\
\hline Aa. cir. ili. prof. et supf. & 3 & 5 & $8(16.3 \%)$ & 3 & 3 & $6(12.2 \%)$ & $14(14.2 \%)$ \\
\hline $\begin{array}{l}\text { A. circumflexa femoris } \\
\text { lateralis }\end{array}$ & 2 & 3 & $5(10.2 \%)$ & 2 & 1 & $3(6.1 \%)$ & $8(8.1 \%)$ \\
\hline $\begin{array}{l}\text { A. cir. ili. prof., A. glut. } \\
\text { sup. }\end{array}$ & 1 & 1 & $2(4.2 \%)$ & & 2 & $2(4.0 \%)$ & $4(4.0 \%)$ \\
\hline $\begin{array}{l}\text { A. cir. ili. supf., A. glut. } \\
\text { sup. }\end{array}$ & & & & & 1 & $1(2.0 \%)$ & $1(1.0 \%)$ \\
\hline A. glutea superior & & & & 1 & & $1(2.0 \%)$ & $1(1.0 \%)$ \\
\hline Total & 18 & 20 & $|38(77.5 \%)|$ & 19 & 22 & $41(83.6 \%)$ & $79(80.6 \%)$ \\
\hline
\end{tabular}

arose independently without formation of the common trunk of origin which is the iliolumbar artery (2\%) and another case in which the iliolumbar artery was absent (2\%).

In the former case, the lumbar branch on each side arose from the common iliac artery while the iliac branch was from the internal iliac artery and the superior gluteal artery. As for the relation with the nerves, both the lumbar and iliac branches on one side followed the same course. That is, they passed on the medial side of the lumbosacral trunk and the obturator nerve. On the other side, the lumbar branch passed on the medial side of the lumbosacralis trunk and on the lateral side of the obturator nerve while the iliac branch passed on the medial side of the lumbosacral trunk and the obturator nerve.

In the latter case, in which the iliolumbar artery was absent, the deep circumflex iliac artery was extremely well developed and extended as far as the quadratus lumborum so that it appeared as if it compensated the absence of the iliolumbar artery.

The findings of $\mathrm{Popowsky}$, etc. on the origin of this artery in primates are summarized as follows: In Prosimiae, it arises in the majority of cases from the caudal artery or the aorta while 
in lower types of Platyrrhinae and Catarrhinae, it is from the common iliac artery or the external iliac artery. Only in higher monkeys does it arise from the internal iliac artery or the superior gluteal artery as in man. In other words, from the standpoint of system genesis, the origin is more distal as the animal advances from lower species to higher species. In addition, there is a change in the origin from the external iliac artery to the internal iliac artery. However, origin from the common iliac artery which is said to be the common condition in lower monkeys may be seen in rare case even in man and likewise even in my cases of Macacus cyclopsis there occasionally was seen among the many cases examined origin from the caudal artery, which is the usual condition in Prosimiae, or origin from the internal iliac artery, which is the normal type in higher monkeys (Table 5).

Review of the frequency of independent origin of the two branches and the absence of this artery shows that in general the iliolumbar ariery is present in primates. The lumbar and iliac branches are considered to rarely arise independently. Comparison of my findings with the statistical computation on Macacus rhesus and Cercopithecus aethiops by Us u i and that on Macacus rhesus by I mai shows that the condition in Macacus rhesus $(100 \%)$ of I $\mathrm{m}$ a i and that in Cercopithecus aethiops (83.3\%) of U s u i generally are same as in my cases of Macacus cyclopsis. However, there is considerable difference from the Macacus rhesus of Usui. That is, in the Macacus rhesus of I mai, there was formation of the iliolumbar artery in all cases whereas in the Macacus rhesus of $\mathrm{Usui}$, the number of cases in which trunk formation was seen is only about one third of the number in which it is absent. It is difficult to explain this difference in the findings between separate studies on the same species, but it possibly may be due to the insufficient number of cases examined. Even in man (Japanese adults, A d a hi, Tsukamoto), common trunk formation is not seen in a considerable number of cases (25-21\%) (Table 6).

Absence of this artery seen in rare cases of my Macacus cyclopsis has been reported in Platyrrhinae by $\mathrm{Fr}$ a $\mathrm{n}$ se $\mathrm{n}$ (according to I $\mathrm{mai}$ ). In such cases, it is compensated by the transverse lumbar artery. Since the absence of this artery in Macacus cyclopsis was compensated by the deep circumflex iliac artery, it may be said that this artery is compensated by a branch of the external iliac artery in cases in which it is absent. Although the original manuscript of $\mathrm{Franse} n$ is not available and no definite statement 

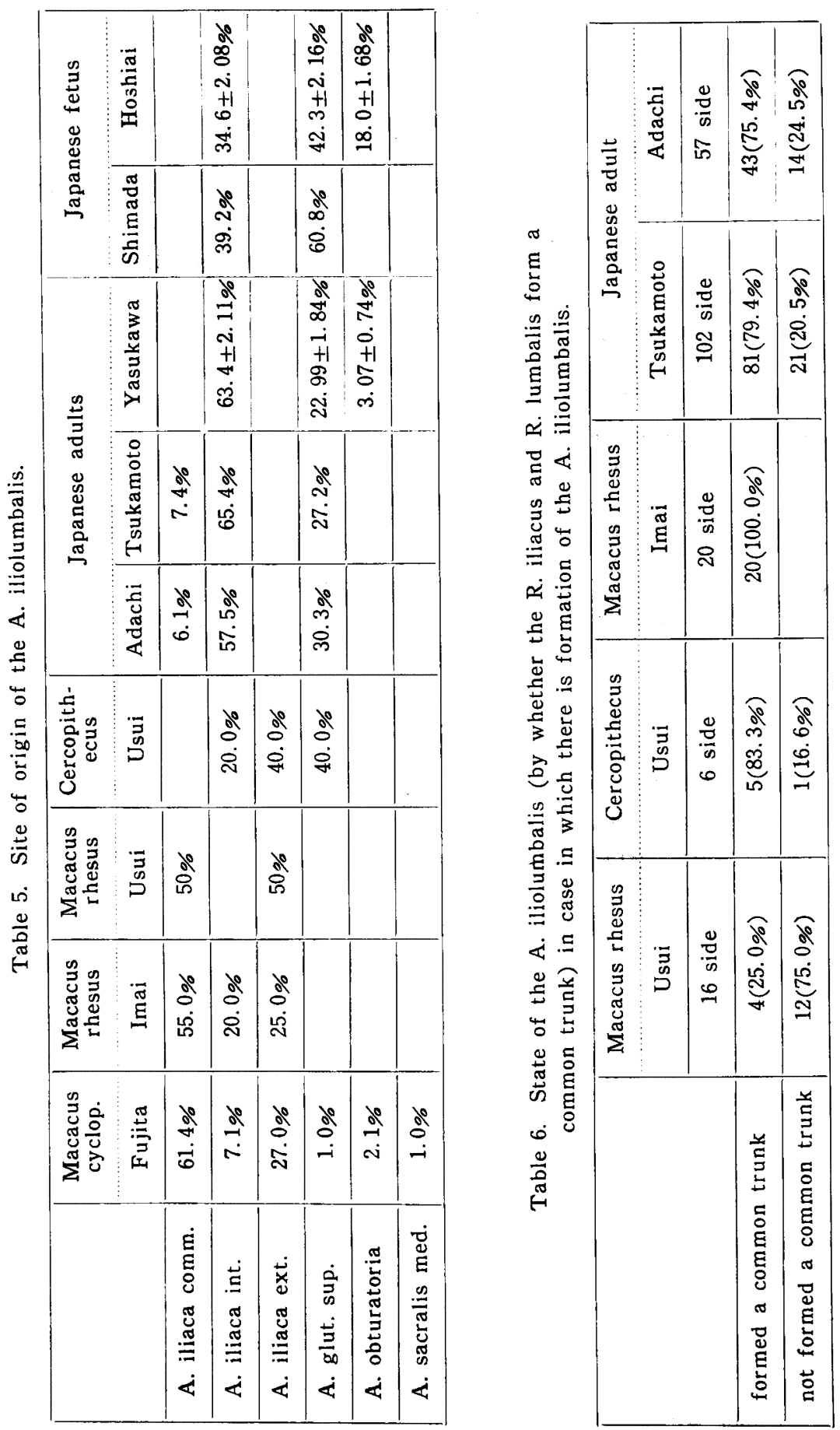
can be said, it is unlikely that this artery is absent in all cases of Platyrrhinae in view of the findings of other studies by Popow s ky, etc.

In the cases in which there is the formation of the iliolumbar artery, the relation of this artery to the nerves is as follows. In Macacus cyclopsis, it passes in front of the lumbosacral trunk. It more frequently runs in front of the obturator nerve than behind the obturator nerve. This condition is the same as in Macacus rhesus. In man, however, it usually passes behind the obturator nerve and very rarely passes in front. Although there are some cases in which it passes in front of the lumbosacral trunk and the obturator nerve, the findings in man differ greatly from that in macaques (Table 7 ). This is felt to be closely related to the fact

Table 7. Relation between the $A$. iliolumbalis and nerve.

\begin{tabular}{|l|c|c|c|c|}
\hline & $\begin{array}{c}\text { Macacus } \\
\text { cyclop. }\end{array}$ & $\begin{array}{c}\text { Macacus } \\
\text { rhesus }\end{array}$ & $\begin{array}{c}\text { Japanese } \\
\text { adult }\end{array}$ \\
\hline $\begin{array}{c}\text { Inside of Tr. nervi } \\
\text { lumbosacralis }\end{array}$ & Inside of N. obt. & $57(60.6 \%)$ & $14(70.0 \%)$ & $1(5.0 \%)$ \\
\cline { 2 - 4 } & Outside of N. obt. & $37(39.3 \%)$ & $6(30.0 \%)$ & $15(75.0 \%)$ \\
\hline Outside of Tr. nervi lumbosacralis and N. obt. & & & $4(20.0 \%)$ \\
\hline
\end{tabular}

that in macaques this artery arises from the common iliac artery or the external iliac artery whereas in man it is from the internal iliac artery or the superior gluteal artery.

The condition of anastomosis of this artery with other arteries is not much different from the findings for Macacus rhesus of I $\mathrm{m}$ a $\mathrm{i}$.

\section{A. iliaca externa}

The common iliac artery separates into the external iliac artery and the internal iliac artery on the anterior surface of the sacroiliac joint usually at the level of the promontorium.

The external iliac artery, accompanied on its medial side by the vein of the same name, descends along the medial side of the psoas major, to which muscular branches are given off. It then emerges in the lacuna vasorum where it becomes the femoral artery. Its branches are the inferior epigastric artery, deep external pudendal artery and the deep circumflex iliac artery. The iliolumbar artery also is frequently given off. The size of the external iliac artery is about equal to the internal iliac artery. 
The level of separation of the common iliac artery on each side into the internal iliac artery and the external iliac artery in relation to the vertebra is as follows. On either side, separation at the level of the promontorium is most frequent (left $34 \%$, right $42 \%$ ). This is followed in frequency by separation at between the upper and lower parts of the promontorium, in other words between the seventh lumbar vertebra and the first sacral vertebra $(24 \%)$ and separation at the upper third of the first sacral vertebra $(24 \%)$. Furthermore, the level of separation in female is higher than in male and in both sex, separation on the right side frequently was higher than on the left side (Table 8). When the level of separation on each side was compared in any one animal, the separation on the left side was more frequently higher in male while there was no difference between the two sides in the majority of female cases (Table 9).

Table 8. Level of bifurcation of the A. iliaca interna and A. iliaca externa.

\begin{tabular}{|c|c|c|c|c|c|c|c|c|}
\hline & \multicolumn{3}{|c|}{$\mathrm{r}$} & \multicolumn{3}{|c|}{1} & \multirow{2}{*}{ total } \\
\hline & & $\hat{o}$ & 우 & $\hat{o}+$ 우 & $\hat{o}$ & 우 & $\hat{\delta}+q$ & \\
\hline \multirow{3}{*}{$\begin{array}{l}\text { VIIth-vertebral } \\
\text { body }\end{array}$} & upper & & & & & & & \\
\hline & middle & 1 & & 1 & & & & $1(1.0 \%)$ \\
\hline & under & 2 & & 2 & 4 & 3 & 7 & $9(9.0 \%)$ \\
\hline \multicolumn{2}{|c|}{ VIIth-intervertebral disc } & 4 & 12 & 16 & 3 & 5 & 8 & $24(24.0 \%)$ \\
\hline \multicolumn{2}{|c|}{ promontory of sacrum } & 9 & 8 & 17 & 6 & 15 & 21 & $38(38.0 \%)$ \\
\hline \multirow{3}{*}{$\begin{array}{l}\text { Ist-sacral } \\
\text { vertebrae }\end{array}$} & upper & 7 & 5 & 12 & 10 & 2 & 12 & $24(24.0 \%)$ \\
\hline & middle & & 1 & 1 & & 1 & 1 & $2(2.0 \%)$ \\
\hline & under & & 1 & 1 & & 1 & 1 & $2(2.0 \%)$ \\
\hline \multicolumn{2}{|l|}{ total } & 23 & 27 & 50 & 23 & 27 & 50 & 100 \\
\hline
\end{tabular}

Table 9. Comparison of the level of bifurcation of the A. iliaca interna and A. iliaca externa to each side.

\begin{tabular}{|c|c|c|c|}
\hline & $\hat{\delta}$ & 우 & total \\
\hline higher on right side & 10 & 8 & $18(36.0 \%)$ \\
\hline equal height & 7 & 12 & $19(38.0 \%)$ \\
\hline higher on left side & 6 & 7 & $13(26.0 \%)$ \\
\hline total & 23 & 27 & 50 \\
\hline
\end{tabular}


The separation of this artery and the internal iliac artery in primates is said to occur on the anterior surface of the sacroiliac joint (Popowsky, Z u ckerkand le), but the only detailed reports available on the site of separation are those of $I \mathrm{~m}$ a $i$ and $\mathrm{Usu}$. When the findings for my Macacus cyclopsis are compared with those of $\mathrm{Us} \mathrm{u}$ i for Macacus rhesus and Cercopithecus aethiops, and that of I mai for Macacus rhesus, it appears that there are more cases of separation at a somewhat lower level in Macacus rhesus of I ma i, but it may be said that the findings of $U \mathrm{~s} u$ i for Macacus rhesus and Cercopithecus aethiops differ little from my findings for Macacus cyclopsis (Table 10).

Table 10. Level of bifurcation of the A. iliaca interna and A. iliaca externa.

\begin{tabular}{|c|c|c|c|c|c|}
\hline & & $\begin{array}{c}\text { Macacus } \\
\text { cyclop. } \\
\text { Fujita }\end{array}$ & $\begin{array}{c}\text { Macacus } \\
\text { rhesus } \\
\text { Usui }\end{array}$ & $\begin{array}{c}\text { Cercopithecus } \\
\text { Usui }\end{array}$ & $\begin{array}{c}\text { Macacus } \\
\text { rhesus } \\
\text { Imai }\end{array}$ \\
\hline \multicolumn{2}{|c|}{ VIth-intervertebral disc } & & $1(6.2 \%)$ & & \multirow{5}{*}{$3(15.0 \%)$} \\
\hline \multirow{3}{*}{$\begin{array}{l}\text { VIIth-vertebral } \\
\text { body }\end{array}$} & upper & & & & \\
\hline & middle & $1(1.0 \%)$ & $1(6.2 \%)$ & & \\
\hline & under & $9(9.0 \%)$ & $3(18.7 \%)$ & $2(33.3 \%)$ & \\
\hline \multicolumn{2}{|c|}{ VIIth-intervertebral disc } & $24(24.0 \%)$ & \multirow{2}{*}{$6(37.5 \%)$} & \multirow{2}{*}{$3(50.0 \%)$} & \\
\hline \multicolumn{2}{|c|}{ promontory of sacrum } & $38(38.0 \%)$ & & & $7(35.0 \%)$ \\
\hline \multirow{3}{*}{$\begin{array}{l}\text { Ist-sacral } \\
\text { vertebrae }\end{array}$} & upper & $24(24.0 \%)$ & $1(6.2 \%)$ & & \multirow{3}{*}{$10(50.0 \%)$} \\
\hline & middle & $2(2.0 \%)$ & $3(18.7 \%)$ & $1(16.6 \%)$ & \\
\hline & under & $2(2.0 \%)$ & $1(6.2 \%)$ & & \\
\hline \multicolumn{2}{|l|}{ total } & 100 & 16 & & 20 \\
\hline
\end{tabular}

In man, the level of separation of the internal iliac artery in

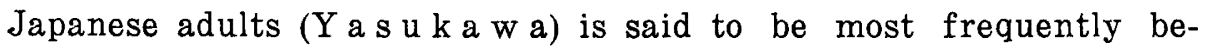
tween the fifth lumbar verbetra and the first sacral vertebra $(23.3 \%)$ followed in frequency by separation at the upper third of the first sacral vertebra (21.8\%), middle third of the fifth lumbar vertebra $(20.3 \%)$ and the lower third of the fifth lumbar vertebra (19.3\%). Even in Japanese fetus ( $\mathrm{Shimada}$ ), most frequently seen is separation at between the fifth lumbar vertebra and the first sacral vertebra $(24.9 \%)$ followed by that at the middle third of the fifth lumbar vertebra (19.1\%) and the lower third of the fifth lumbar 
vertebra (16.2\%). In either case the level of separation is at about the level of the promontorium which is similar to the condition in monkey.

\section{(1) A. epigastrica inferior}

This artery arises from the external iliac artery (90\%) and occasionally from the internal iliac artery or its branch (10\%) at above or near the Arcus inguinalis. It runs medialward and downward to the internal inguinal ring where it turns sharply upward and ascends along the inner surface of the abdominal wall. It anastomoses with the superior epigastric artery at near the umbilicus.

At the internal inguinal ring, it usually gives off the deep external pudendal artery $(75 \%)$ and one or two pubic branches are sent off to the inner surface of the horizontal part of the pubis which sometimes may anastomose with the pubic branch of the obturator artery (10\%).

As mentioned previously, this artery usually forms a common trunk with the deep external pudendal artery. The pudendo-epigastricus trunk (the common trunk formed by the deep external pudendal artery and inferior epigastric artery) arises either from the external iliac artery $(71 \%)$ or the medial circumflex femoral artery $(4 \%)$. When viewed primarily from the standpoint of the medial circumflex femoral artery, there are cases in which the common trunk formed with this artery arises from the external iliac artery $(2 \%)$ and that in which it arises from the internal iliac artery or

Table 11. Site of origin of the A. epigastrica inferior.

\begin{tabular}{|c|c|c|c|c|c|c|c|c|}
\hline & \multicolumn{3}{|c|}{$\mathrm{r}$} & \multicolumn{3}{|c|}{1} & \multirow{2}{*}{ total } \\
\hline & & $\hat{o}$ & 우 & $\hat{o}+$ 우 & $\hat{\delta}$. & 우 & $\hat{\delta}+q$ & \\
\hline \multicolumn{2}{|c|}{ A. iliaca externa } & 22 & 22 & 44 & 20 & 24 & 44 & $88(88.0 \%)$ \\
\hline \multirow{2}{*}{$\begin{array}{l}\text { A. cir. } \\
\text { fem. med. }\end{array}$} & $\begin{array}{l}\text { divided from } \\
\text { A. iliaca ext. }\end{array}$ & & 1 & 1 & & 1 & 1 & $2(2.0 \%)$ \\
\hline & $\begin{array}{l}\text { divided from } \\
\text { A. iliaca int. }\end{array}$ & 1 & 3 & 4 & 2 & 1 & 3 & $7(7.0 \%)$ \\
\hline \multicolumn{2}{|c|}{$\begin{array}{l}\text { A. obt. (divided from } \\
\text { A. iliaca int.) }\end{array}$} & & & & & 1 & 1 & $1(1.0 \%)$ \\
\hline \multicolumn{2}{|c|}{$\begin{array}{l}\text { Tr. obturatorio-femoralis } \\
\text { (divided from A. iliaca int.) }\end{array}$} & & 1 & 1 & 1 & & 1 & $2(2.0 \%)$ \\
\hline \multicolumn{2}{|c|}{ total } & 23 & 27 & 50 & 23 & 27 & 50 & 100 \\
\hline
\end{tabular}


Table 12. Site of origin of the common trunk formed by the

A. pudenda externa profunda and A. epigastrica inferior.

\begin{tabular}{|c|c|c|c|c|c|c|c|}
\hline & \multicolumn{3}{|c|}{$\mathrm{r}$} & \multicolumn{3}{|c|}{1} & \multirow{2}{*}{ total } \\
\hline & $\hat{\delta}$ & 우 & $\delta+q$ & $\hat{o}$ & 우 & $\delta+q$ & \\
\hline A. iliaca externa & 16 & 20 & 36 & 14 & 21 & 35 & $71(94.6 \%)$ \\
\hline $\begin{array}{l}\text { A. cir. fem. med. (divided } \\
\text { from A. iliaca int.) }\end{array}$ & & 2 & 2 & 1 & 1 & 2 & $4(5.4 \%)$ \\
\hline total & 16 & 22 & 38 & 15 & 22 & 37 & 75 \\
\hline
\end{tabular}

its branch (9\%) (Tables 11 and 12).

Previous reports of the findings on the origin in primates by Popowsky, Usui, etc., indicate that the origin is usually from the external iliac artery or the medial circumflex femoral artery. However, among Prosimiae, it is reported to form a common trunk with the circumflex iliac artery in Hapale rosalia and Hapale penicillata, while a common trunk is formed with the obturator artery in Cebus hypoleucus of Platyrrhinae, and in Macacus cynomolgus and Orang-utan of Catarrhinae (Popow sky). These findings, in particular the findings of $U \mathrm{~s} \mathrm{u} i$ and $\mathrm{I} \mathrm{m}$ a $\mathrm{i}$ for Macacus rhesus are almost identical to my findings for Macacus cyclopsis.

An arterial branch is said to be sent off from this artery to the external genital region in all monkeys ( $\mathrm{Popowsky}$. This finding was likewise demonstrated in my cases of Macacus cyclopsis.

In man, this artery most often arises from the external lliac artery and occasionally from the femoral artery but there is no instance of origin from the internal iliac artery (A d a c h i, T s u kamoto). Thus, the condition in man is not entirely the same as in Primates. However, the close relation with the obturator artery is the same as in Primates.

(2) A. pudenda externa

The arteries to the external genital region in monkey, unlike the condition in man, arise in the majority of cases by a common trunk with the inferior epigastric artery. Usui has classified these into the deep external pudendal artery and the superficial external pudendal artery. The deep external pudendal artery corresponds to the external spermatic artery (A. ligamenti teretis uteri) of man, but in view of its origin, course and distribution the name applied by $\mathrm{Usu}$ i appears to be most appropriate for 
monkey and will be used here.

(i) A. pudend externa superficialis

In most cases, this artery arises from the femoral artery by a common trunk with the superficial epigastric artery. It runs medialward and downward to supply the skin and subcutaneous region of the external genital region. In no case does it arise from the region of the external iliac artery and thus it should be considered to be a branch of the femoral artery. Although this artery has been mentioned previously in the report of $\mathrm{Tu}$ of this department, its discussion had been comparatively brief and therefore will be described here in more detail.

\section{(a) A. pudend externa superficialis superior}

This artery arises at about the level of the fossa ovalis from either the femoral artery $(65 \%)$ or the deep femoral artery $(23 \%)$ or from the region of bifurcation of these arteries $(12 \%)$. It passes medio-downward through the lymph nodes in this region to which several small branches are given off. It is distributed to the subcutaneous region of the upper medial side of the thigh and in males supplies the anterior surface of the scrotum and the subcutaneous region of the dorsal side of the penis while in female it supplies the labia majora but is not as well developed as in male.

The origin of this artery is independent only in a small number of cases (11\%) and in most cases forms a common trunk with other arteries. Most frequent are the formation of a common trunk with both the superficial circumflex iliac artery and the sperficial epigastric artery (35\%), formation of a common trunk with only the superficial epigastric artery (23\%) and the formation of a common trunk with only the superficial circumflex iliac artery (15\%). The formation of a common trunk with other arteries is very rare (Table 13).

The dorsal subcutaneous artery of the penis which usually is a large artery arises from the deep external pudendal artery. Occasionally, it may arise from the superior superficial external artery (23.9\%). During its course, in some cases the artery on each side may anastomose at the dorsal surface of the base of the penis (clitoris) (4\%) or there may be anastomosis with the deep external pudendal artery $(6 \%)$ or with the inferior super- 





ficial external pudeñdal artery (14\%), and in occasional cases it may pass behind the gracilis to the subcutaneous region where it anastomoses with the anterior branch of the medial circumflex femoral artery (4\%). The artery which $\mathrm{Tu}$ simply mentions as the A. pudenda externa superficialis corresponds to this artery.

(b) A. pudenda externa superficialis inferior

Tris is a small artery which arises from the femoral artery after it has passed through the adductor canal $(77 \%)$ or from the region of bifurcation of the popliteal and the saphenous arteries (17\%) and occasionally from the popliteal artery (4\%) or the saphenous artery (2\%). It runs upward and medialward beneath the skin on the medial side of the thigh to supply the anterior surface of the scrotum (labia majora) and the dorsal side of the penis (clitoris). It is particularly poorly developed in female.

Independent origin (56\%) and origin by a common trunk with the genu suprema artery (41\%) are seen at about equal frequency and in rare cases it forms a common trunk with the

Table 14. Site and state of origin of the A. pudenda externa superficialis inferior.

\begin{tabular}{|c|c|c|c|c|c|c|c|c|}
\hline \multirow{2}{*}{\multicolumn{2}{|c|}{ state of origin site of origin }} & \multicolumn{3}{|c|}{$r$} & \multicolumn{3}{|c|}{1} & \multirow{2}{*}{ total } \\
\hline & & $\hat{\jmath}$ & 우 & 우우 & $\delta$ & 우 & $\hat{o}+q$ & \\
\hline \multirow{4}{*}{$\begin{array}{l}\text { independent } \\
\text { origin }\end{array}$} & A. femoralis & $12(1)$ & $10(3)$ & $22(4)$ & 9 & $19(6)$ & $28(6)$ & $50(10)$ \\
\hline & $\begin{array}{l}\text { Bifurcation of } \mathrm{A} \text {. } \\
\text { poplitea and } \mathrm{A} \text {. } \\
\text { saphena }\end{array}$ & 2 & & 2 & & & & 2 \\
\hline & A. poplitea & & 2 & 2 & $2(1)$ & & $2(1)$ & $4(1)$ \\
\hline & total & $14(1)$ & $12(3)$ & $26(4)$ & $11(1)$ & $19(6)$ & $30(7)$ & $56(11)$ \\
\hline \multirow{4}{*}{$\begin{array}{l}\text { common trunk } \\
\text { formed by A. } \\
\text { genus suprema }\end{array}$} & A. femoralis & 4 & $11(3)$ & $15(3)$ & $7(1)$ & $1(1)$ & $8(2)$ & $23(5)$ \\
\hline & $\begin{array}{l}\text { Bifurcation of } \mathrm{A} \text {. } \\
\text { poplitea and } \mathrm{A} \text {. } \\
\text { saphena }\end{array}$ & $4(1)$ & $4(1)$ & $8(2)$ & 3 & $5(1)$ & $8(1)$ & $16(3)$ \\
\hline & A. saphena & & & & 1 & 1 & 2 & 2 \\
\hline & total & $8(1)$ & $15(4)$ & $23(5)$ & $11(1)$ & $7(2)$ & $18(3)$ & $41(8)$ \\
\hline $\begin{array}{l}\text { common trunk } \\
\text { formed by A. } \\
\text { pud. ext. supf. } \\
\text { sup. }\end{array}$ & A. femoralis & 1 & & 1 & 1 & 1 & 2 & 3 \\
\hline \multicolumn{2}{|c|}{ total } & $23(2)$ & $27(7)$ & $50(9)$ & $23(2)$ & $27(8)$ & $50(10)$ & $100(19)$ \\
\hline
\end{tabular}

Shown in ( ) are the cases which could not be traced to the pubic region. 
superior superficial external pudendal artery (3\%). In either case, however, the origin is usually from the femoral artery (Table 14).

The branches of this artery include the comparatively well developed branches which supply the adductor longus, adductor magnus and the gracilis. In addition, branches are given off which anastomose on the medial side of the upper thigh or the lateral surface of the root of the penis (clitoris) with the deep external pudendal artery (17\%), the superior superficial external pudendal artery $(14 \%)$, or both of these arteries $(16 \%)$ or with the anterior branch of the medial circumflex femoral artery $(12 \%)$. The R. cutaneus of the A. cutaneus of Bluntschli corresponds to this artery and $\mathrm{T} u$ also has used this nomenclature.

According to Popowsky and Bluntschli, the superficial external pudendal artery in Prosimiae and in many Catarrhinae arise from the femoral artery by a common trunk with the superficial circumflex iliac artery and the superficial epigastric artery (the common subcutaneous trunk). In some animals (Cercopithecus entellus, Cercopithecus pygerythrus), the external pudendal artery arises from the femoral artery by a common trunk with the superficial epigastric artery (the pudendo-epigastric trunk). In contrast to this, in some Platyrrhinae (Cebus, Ateles), the external pudendal artery may form separate common trunks with the superficial epigastric artery and the superficial circumflex iliac artery both of which arise from the femoral artery, but occasionally the external pudendal artery may arise independently from the dorsal artery of the clitoris (Nyctipithecus vociferaus).

Among the studies on Catarrhinae, there are reports by $\mathrm{Us} \mathrm{u}$, I $\mathrm{ma} \mathrm{i}$ and $\mathrm{Tu}$ on macaques in addition to the description by $\mathrm{Bluntschli}$. It is said that in Macacus rhesus the formation of the common subcutaneous trunk is the most frequent as in my cases of Macacus cyclopsis. The lateral circumflex femoral artery is reported to be associated with the formation of the common subcutaneous trunk in Macacus cynomolgus and Macacus nemestricus (Bluntschli). In the Macacus cyclopsis examined by $\mathrm{Tu}$, the common subcutaneous trunk was infrequently seen while the pudendo-epigastric trunk was frequent. The low frequency of common trunk formation with the superficial circumflex iliac artery together with the comparatively high frequency of independent origin of 
this artery in the Macacus cyclopsis of $\mathrm{T} \mathrm{u}$ appears to be somewhat strange. However, the close relation between this artery and the superficial epigastric artery with which there is formation of a common trunk agrees with my findings.

In man, the independent origin of the external pudendal artery is usual $(82 \%)$. In the remaining cases, there is formation of an incomplete pudendo-epigastric trunk or an incomplete common subcutaneous trunk. In either case, the origin is from the femoral artery $(\mathrm{A} \mathrm{d} \mathrm{a} \mathrm{c} \mathrm{h} \mathrm{i})$. Consequently, this finding along with the fact that the superior superficial external pudendal artery and the inferior superficial external pudendal artery form a common trunk in many cases indicate that there is considerable difference between man and primates with regard to the condition of formation of a common trunk with other arteries. In other words, it appears that in primates, in particularly lower primates, there is greater tendency for the formation of a common trunk with surrounding arteries.

The inferior superficial external pudendal artery corresponds to the R. cutanei of the A. musculocutanea distalis of B l u $\mathrm{nts} \mathrm{chli.}$ $\mathrm{T} \mathrm{u}$ also has used this classification (nomenclature), but in view of its distribution, I feel that the most appropriate term is inferior superficial external pudendal artery of $U s u i$, who in his report says that the origin of this artery is located considerably more proximal in Lemur and Semnopithecus while in Cercopithecus it is closer to the bifurcation of the femoral artery being slightly proximal to the location where the femoral artery crosses over the lower edge of the adductor longus.

This artery in Macacus cyclopsis, as reported by $\mathrm{T} u$, is also in the greater majority of cases given off from the femoral artery after its passage through the adductor canal. This finding generally agrees with that of $\mathrm{Usu}$ i for Macacus rhesus and Cercopithecus aethiops. In the report by I $\mathrm{m}$ a $\mathrm{i}$ on Macacus rhesus, however, the majority of cases was said to arise from the muscular branch of the deep femoral artery (55\%). In my cases of Macacus cyclopsis, this artery in most cases arises by a commou trunk with the genu suprema artery as in the Macacus rhesus of Usui (41\%). There is no mention of such a finding in the reports by $\mathrm{Z} \mathrm{u} \mathrm{ckerkandl}$ and $\mathrm{Tu}$.

In man, the inferior superficial external pudendal artery supplies the scrotum (labia majora). At beneath the skin of the scrotum and septum scroti in male, and in the superficial and deep layers 
of the labia in female, there is anastomosis with the septal artery of the scrotum, the anterior scrotal artery (anterior labial artery) and the posterior scrotal artery (posterior labial artery) of the perineal artery ( $\mathrm{K}$ a to). Thus, there appears to be a considerable difference from the condition of anastomosis in monkey.

(ii) A. pudenda externa profunda

This is a comparatively well developed artery which usually arises from the external iliac artery (87\%). It also may arise from the medial circumflex femoral artery $(8 \%)$ or from the femoral artery (5\%).

When this artery arises from the so-called external iliac artery within the pelvis, it emerges from inguinal canal accompanied by the vein of the same name while in cases in which the origin is from the femoral artery it runs along the arcus inguinalis. This artery runs medialward along the anterior surface of the thigh to the medial side of the spermatic cord in male from where it descends beneath the skin on the anterior surface of the symphysis pubis. Small branches are given off to the subcutaneous region of the external genital region, and the terminal branch always anastomoses with the perineal artery in the perineal region. In addition, branches are given off to the anterior surface of the sciatic tuberosity. Furthermore, the deep external pudendal artery on each side anastomose at the upper edge of the symphysis pubis, the base of the penis (clitoris) or the perineal region.

The origin of this artery in most cases is by a common trunk with the inferior epigastric artery (75\%). There also

Table 15. Site of origin of the A. pudenda externa profunda (Independent origin).

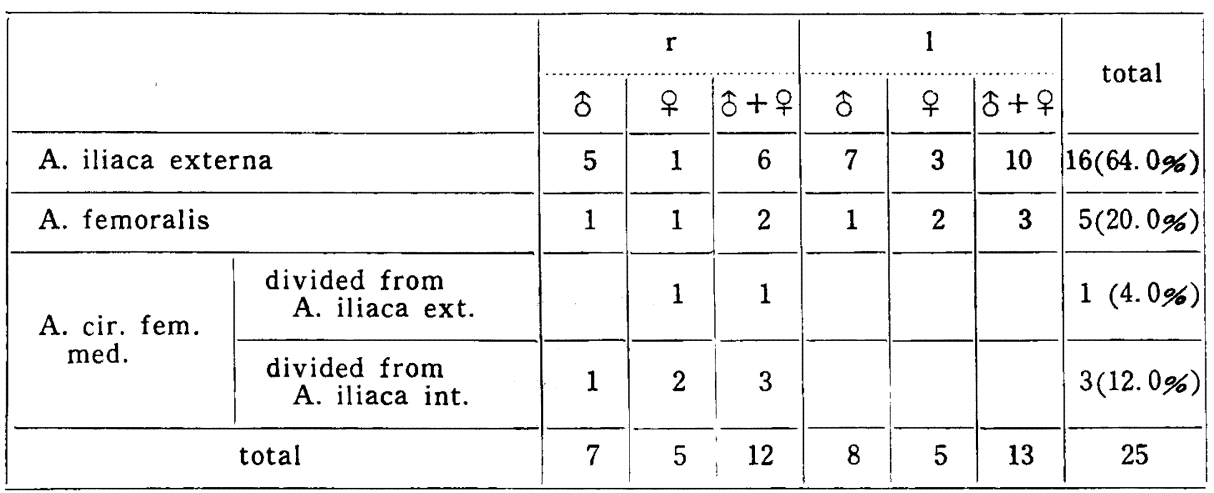


may be origin by a common trunk with the medial circumflex femoral artery $(8 \%)$ most of which arise from the internal iliac artery. Origin from the external iliac artery was seen in only one case. The cases in which this artery arose from the femoral artery were all by independent origin (Tables 12 and 15).

According to Popow sky, in most monkey the external spermatic artery which enters into the inguinal canal and the pubic artery are given off from the inferior epigastric artery. Rojecki also has regarded this artery to be a branch of the inferior epigastric artery. Usui has called the external spermatic artery and the external pudendal artery of Popow sky collectively as the deep external pudendal artery and reports that it arises from the inferior epigastric artery. I $\mathrm{m}$ a $\mathrm{i}$ reports that the main arterial trunk to the external genital region of Macacus rhesus arises from the inferior epigastric artery and that this artery corresponds to the external spermatic artery or the A. ligamenti teretis uteri of man. Therefore, he has used this nomenclature. He further reports that the artery corresponding to the deep external pudendal artery of man is absent. Thus, my findings on the origin and other conditions in Macacus cyclopsis agree with their findings. The origin from the medial circumflex femoral artery which had been noted in Macacus cyclopsis has been reported by Usui as being exceptional. Also, the fact that the common trunk formed with the medial circumflex femoral artery almost always arises from the internal iliac artery is to be expected because the origin of the medial circumflex femoral artery in macaques is, unlike the condition in man, usually from the internal iliac artery.

In man, the external spermatic artery, which arises from the inferior epigastric artery, descends along the spermatic cord to the testicle. During its course branches are given off to the cremaster and the spermatic cord. The branch to the lateral side anastomoses with the scrotal artery while the A. ligamenti teretis uteri, which supplies the ligamentum teres uteri and the labium majus, is very poorly developed. Furthermore, the artery called the deep external pudendal artery which supplies the deep layer of the external genital region in man arises from the area of the femoral artery and passes behind the femoral vein. In monkey, however, such an artery is not found, but the condition of anastomosis between this artery on each side is similar to that of the deep external pudendal artery of man, and therefore it was felt that this 
comparatively well developed artery, which arises from the inferior epigastric artery and supplies the external genital region (scrotum, labium majus), should be termed the deep external pudendal artery as has been termed by Usui. In Macacus cyclopsis, there may be some cases in which it arises from the femoral artery, but in each of these cases it passes in front of the femoral vein rather than behind the femoral vein.

\section{(3) A. circumflex ilium profunda}

This artery in most instances arises from the lateral surface of the external iliac artery $(68 \%)$ or the femoral artery $(19 \%)$. Accompanied by the vein of the same name, it runs lateralward and upward to supply the transversus abdominis and the obliquus abdominis internus. In rare cases, it may arise from the deep femoral artery (2\%) or may even be completely absent (11\%). Among the cases in which it arises from the femoral artery, there may be formation of a common trunk with the superficial circumflex iliac artery (7\%) (Table 16).

Table 16. Site of origin of the A. circumflexa ilium profunda.

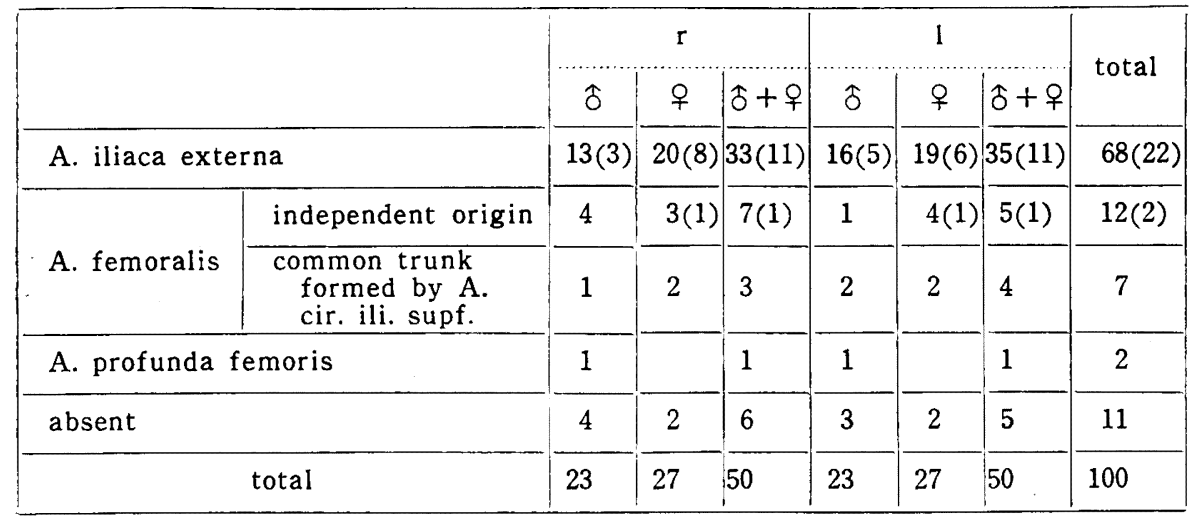

Shown in ( ) are the cases in which the development was comparatively good.

The level of origin of this artery usually is lower than that of the inferior epigastric artery, but there are cases in which it arises at the same level $(10 \%)$ or higher $(6 \%)$.

Because this artery is usually poorly developed, it is supplemented or compensated by the iliac branch of the iliolumbar artery $(86 \%)$ with which there is definite anastomosis in the majority of cases $(44 \%)$. There was, however, a very rare case in which to the contrary it was very highly developed and appeared as if it 
compensated the iliolumbar artery $(2 \%)$.

According to Popowsky and other previous reports, this artery which arises from the external iliac artery is frequently compensated by the iliolumbar artery. In the report of $\mathrm{I} \mathrm{m}$ a $\mathrm{i}$ on Macacus rhesus there is mention of origin from the femoral artery and of absence of this artery such as noted in my cases of Macacus cyclopsis.

In man, however, this artery is well developed and arises from the external iliac artery or the femoral artery. In addition, origin from the femoral artery is considerably more frequent than in our cases of Catarrhinae (A d a c i, Tsu ka moto). In other words, the origin is at a higher level in monkey than in man. A few cases have been seen among man in which this artery consists of two vessels, but there was no such case in Macacus cyclopsis and neither has there been such a report for other primates. In the comparison of the level of origin of the inferior epigastric artery and the deep circumflex iliac artery, it has been reported that in monkey the origin of this artery is lower (more distal) than that

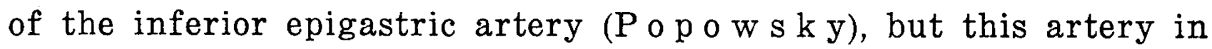
Macacus cyclopsis is not necessarily limited to low origin.

\section{A. caudalis media}

This artery is given off from the dorsal surface of the abdominal aorta slightly above its lower end. It passes behind the region of junction of the common iliac veins from each side or behind the common iliac vein of the left side. After giving off the lowest lumbar artery to each side, it descends between the veins of the same name along the middle of the anterior surface of the lumbar vertebra and sacral vertebra. At between the promontorium and the second sacral vertebra, it sends off the lateral caudal artery to each side after which it passes through the coccygeal vascular arch. It then runs in the subcutaneous along the midline of the anterior surface of the tail to its tip. During this course, muscular branches are sent off to the flexor caudae longus and brevis, and branches which supply the lateral surface of the tail are sent off to both sides at the level of each sacral vertebra and coccygeal vertebra.

In the greater majority of cases (84\%), this artery arises from the dorsal surface of the abdominal aorta, but occasionally it may arise from the common iliac artery (16\%). The origin from the 
common iliac artery, however, most often occurs on the left side. This artery was found to arise from the common iliac artery on the right side in only one case $(2 \%)$.

The level of origin of the medial caudal artery as projected onto the vertebra naturally is related to the height of bifurcation of the common iliac artery, but the origin is slightly above the bifurcation of the common iliac arteries to both sides. Most often the origin corresponds to the upper third of the sixth lumbar vertebra $(32 \%)$, followed in frequency by origin at the level of the middle third of the sixth lumbar vertebra (22\%), the intervertebral cartilage between the fifth and sixth lumbar vertebrae (20\%) and the lower third of the fifth lumbar vertebra (14\%) (Table 17).

Table 17. Site of origin of the A. caudalis media.

\begin{tabular}{|c|c|c|c|c|c|c|c|c|}
\hline \multirow{3}{*}{\multicolumn{2}{|c|}{ height of origin }} & \multicolumn{3}{|c|}{$\delta$} & \multicolumn{3}{|c|}{ 우 } & \multirow{3}{*}{ total } \\
\hline & & \multirow{2}{*}{$\begin{array}{l}\text { Aorta } \\
\text { abdom. }\end{array}$} & \multicolumn{2}{|c|}{$\begin{array}{l}\text { A. iliaca } \\
\text { comm. }\end{array}$} & \multirow{2}{*}{$\begin{array}{r}\text { Aorta } \\
\text { abdom. }\end{array}$} & \multicolumn{2}{|c|}{$\begin{array}{c}\text { A. iliaca } \\
\text { comm. }\end{array}$} & \\
\hline & & & $\mathbf{r}$ & 1 & & $r$ & 1 & \\
\hline Vth-vertebral body & under & 2 & & & 5 & & & $7(14.0 \%)$ \\
\hline \multicolumn{2}{|l|}{ Vth-intervertebral disc } & 6 & & & 4 & & & $10(20.0 \%)$ \\
\hline \multirow{3}{*}{ VIth-vertebral body } & upper & 3 & 2 & & 10 & 1 & & $16(32.0 \%)$ \\
\hline & middle & 4 & 1 & 1 & 4 & 1 & & $11(22.0 \%)$ \\
\hline & under & 2 & & & 1 & 1 & & $4(8.0 \%)$ \\
\hline \multicolumn{2}{|c|}{ VIth-intervertebral disc } & 1 & & & & & & $1(2.0 \%)$ \\
\hline VIIth-vertebral body & upper & & 1 & & & & & $1(2.0 \%)$ \\
\hline \multicolumn{2}{|l|}{ total } & 18 & 4 & 1 & 24 & 3 & & 50 \\
\hline
\end{tabular}

There was one exceptional case in which this artery arose from the right common iliac artery and passed in front of the common iliac vein (Male, one case) while in another case the lowest lumbar artery arose from the internal iliac artery and ran along the front of the common iliac vein around to the dorsal side of the common iliac vein and artery (male, 1 case).

\section{(1) A. caudalis lateralis}

This artery supplies the upper half of the tail and usually is sent off from the medial caudal artery at the level of the first sacral vertebra $(66 \%)$ or the promontorium $(22 \%)$. In a very rare 
Table 18. Site of origin of the A. caudalis lateralis.

\begin{tabular}{|c|c|c|c|c|c|c|c|c|}
\hline \multirow{2}{*}{$\begin{array}{c}\text { site of } \\
\text { origin }\end{array}$} & \multirow[b]{2}{*}{ heigh of origin } & \multicolumn{3}{|c|}{$\mathrm{r}$} & \multicolumn{3}{|c|}{1} & \multirow{2}{*}{ total } \\
\hline & & $\hat{\delta}$ & 우 & $\hat{\delta}+$ 우 & $\hat{\delta}$ & 우 & $\delta+$ 우 & \\
\hline \multirow{4}{*}{$\begin{array}{l}\text { Aorta } \\
\text { abdom. }\end{array}$} & VIIth-vertebral body & 2 & & 2 & 2 & & 2 & $4(4.0 \%)$ \\
\hline & Promontory of sacrum & 6 & 4 & 10 & 6 & 6 & 12 & $22(22.0 \%)$ \\
\hline & Ist-sacral body & 14 & 18 & 32 & 14 & 20 & 34 & $66(66.0 \%)$ \\
\hline & IInd-sacral body & 1 & 4 & 5 & 1 & 1 & 2 & $7(7.0 \%)$ \\
\hline $\begin{array}{l}\text { A. iliaca } \\
\text { comm. }\end{array}$ & VIth-intervertebral disc & & 1 & 1 & & & & $1(1.0 \%)$ \\
\hline \multicolumn{2}{|r|}{ total } & 23 & 27 & 50 & 23 & 27 & 50 & 100 \\
\hline
\end{tabular}

case, it was found to arise from the common iliac artery (1\%) (Table 18).

The lateral caudal artery anastomoses with the lateral sacral artery at the anterior surface of the first sacral vertebra near the first sacral foramen.

Table 19. Relation between the A. caudalis lateralis and Arcus vasculosus caudalis.

(1) Cases with five caudal vascular arches

\begin{tabular}{|c|c|c|c|c|c|c|c|}
\hline & \multicolumn{3}{|c|}{ r } & \multicolumn{3}{|c|}{1} & \multirow{2}{*}{ total } \\
\hline & $\delta$ & 우 & $\hat{0}+$ 우 & $\hat{\jmath}$ & 우 & $\hat{\delta}+$ 우 & \\
\hline $\begin{array}{l}\text { IInd. IIIrd. IVth. Vth. VIth. } \\
\text { caudal bodies }\end{array}$ & 10 & 10 & 20 & 9 & 8 & 17 & 37 \\
\hline IInd. IIIrd. IVth. Vth. caudal bodies & 5 & 7 & 12 & 6 & 7 & 13 & 25 \\
\hline IInd. IIIrd. IVth. caudal bodies & 6 & 3 & 9 & 5 & 8 & 13 & 22 \\
\hline IInd. IIIrd. caudal bodies & & 3 & 3 & 1 & 1 & 2 & 5 \\
\hline Caudal arches not penetrated & & 1 & 1 & & & & 1 \\
\hline total & 21 & 24 & 45 & 21 & 24 & 45 & 90 \\
\hline
\end{tabular}

(2) Cases with four caudal vascular arches

\begin{tabular}{|l|r|r|r|r|r|r|r|}
\hline & \multicolumn{1}{|c|}{$r$} & o & $\delta+o$ & $\hat{\delta}$ & o & $\hat{\delta}+$ o & total \\
\hline IInd. IIIrd. IVth. Vth caudal bodies & 2 & 1 & 3 & 2 & 1 & 3 & 6 \\
\hline IInd. IIIrd. IVth. caudal bodies & & 2 & 2 & & 2 & 2 & 4 \\
\hline total & 2 & 3 & 5 & 2 & 3 & 5 & 10 \\
\hline
\end{tabular}


The condition of its passage through the coccygeal vascular arch is as follows. When there are five arches involving the second to sixth coccygeal vertebrae (45 bodies), it most of ten passes through the last vascular arch (37\%). In addition there are instances in which it does not pass through the last vascular arch $(25 \%)$ or cases in which it passes through the last two vascular arches $(22 \%)$ or through the first two vascular arches (5\%). In one case in which the origin of this artery was from the common iliac artery it did not pass through the vascular arch at all but ended further proximal at the level of the first coccygeal vertebra.

In cases in which there are four vascular arches involving the second to fifth coccygeal vertebrae $(10 \%)$, it either passes through the last vascular arch $(6 \%)$ or does not pass through the last vascular arch $(4 \%)$ (Table 19$)$.

(2) A. sacralis mediana accessoria

In one case in which there was the normal presence of the medial caudal artery (medial sacral artery) and its branch the lateral caudal artery, an additional small branch was found that arose from the common iliac artery and passed in front of the common iliac vein to supply the first and second sacral vertebrae (female, right side, 1\%). This corresponds to the so-called accesory medial sacral artery of A d a c hi.

The lateral caudal artery in the previously mentioned case which arose from the common iliac artery followed a similar course as the accessory medial sacral artery, but since the lateral caudal artery was absent on this side and since the course of this artery was the same as the lateral caudal artery, it had been regarded as a case of abnormal origin of the lateral caudal artery rather than considered as the accessory medial sacral artery.

In primates, the caudal artery always arises from the dorsal surface of the abdominal aorta (Hochstetter, etc.), while in anthropoid apes it is reported to have regressed and may be found only as a caudal branch called the medial sacral artery (Popow sky).

This artery in Macacus cyclopsis is comparatively well developed and arises from the dorsal wall of the abdominal aorta or the common iliac artery. Origin from the region of bifurcation reported by $\mathrm{Th}$ i e le in Simia inus was found in no case. In almost all of my cases of Macacus cyclopsis, it gives rise to the lowest lumbar artery and this frequency is much higher than in Macacus rhesus 
(I mai, Usui). There is, however, no difference by sex such as reported by Imai. Nonetheless, the level of origin is generally the same as their findings. The passage of this artery in front of the common iliac vein which had been found in Macacus cyclopsis (male) has not been reported in any other monkey.

In man, this artery of course has regressed and may only be found as the medial sacral artery which usually arises from the dorsal wall of the abdominal aorta or in rare cases from the common iliac artery (A d c hi, Ts u ka moto, A s o).

A d a c hi has frequently observed the accessory medial sacral artery in addition to the caudal artery. This artery arises from the abdominal aorta or the common iliac artery and passes in front of the common iliac vein. One such case was found in Macacus cyclopsis but there are no such report for other monkey.

The anastomosis between the lateral caudal artery and the lateral sacral artery which always was found in Macacus cyclopsis has also been reported by Popow s ky. The level of origin of the lateral caudal artery is slighter lower than that reported in Macacus rhesus by I $\mathrm{m}$ a $\mathrm{i}$ and the state of passage through the last vascular arch also is somewhat different from his findings. In Macacus cyclopsis, this artery accompanies the caudal artery on both sides in the majority of cases whereas in his findings only that on the right side was found to accompany the caudal artery in most cases.

\section{Summary}

\section{A. iliaca communis}

The abdominal aorta separates into the common iliac artery to each side usually at the level of the sixth lumbar vertebra. The common iliac artery frequently sends off the iliolumbar artery and usually passes in front of the lumboscral trunk and the obturator nerve.

The iliolumbar artery separates into the lumbar and iliac branches, but in rare cases each of these branches may arise independently or be absent.

\section{A. iliaca externa}

The common iliac artery separates into the external iliac artery and the internal iliac artery generally at the level of the promontorium. The external iliac artery descends to the vicinity of the arcus inguinalis where it divides into the inferior epigastrica artery, 
deep external pudendal artery and the deep circumflex iliac artery.

The external iliac artery and the internal iliac artery are of about equal size.

\section{(1) A. epigastrica inferior}

This artery most often arises from the external iliac artery by a common trunk with the deep external pudendal artery, but occasionally may arise by a common trunk with either the medial circumflex femoral artery or the obturator artery or by a common trunk with both of these arteries.

It also gives off a branch to the external genital region.

(2) A. pudenda externa

(i) A. pudenda externa superficialis

This artery may be classified into the superior and inferior superficial external pudendal arteries which supply the external genital region. Both are branches of the femoral artery.

The superior superficial external pudendal artery arises from the femoral artery or the deep femoral artery by the common subcutaneous trunk (the common trunk formed by the superficial circumflex iliac artery, superficial epigastric artery and the superficial external pudendal artery) and sometimes there is the formation of the pudendo-epigastric trunk (common trunk formed by the superficial epigastric artery and superficial external pudendal artery with independent origin of the superficial circumflex iliac artery).

The inferior superficial external pudendal artery (A. musculocutanea distalis) which is less developed than the superior superficial external pudendal artery arises independently or by a common trunk with the genu suprema artery.

\section{(ii) A. pudenda externa profunda}

This artery arises either by a common trunk with the inferior epigastric artery or independently from the external iliac artery and in rare cases from the medial circumflex femoral artery or the femoral artery. This artery emerges out of the pelvic cavity to the external genital region where it anastomoses with the superficial external pudendal artery and in addition always anastomoses with the perineal artery as well. 


\section{(3) A. circumflexa ilium profunda}

This artery most often arises from the external iliac artery and occasionally from the femoral artery. It is poorly developed and is compensated by the iliac branch of the iliolumbar artery.

\section{A. caudalis media}

This is a comparatively well developed artery which arises from the dorsal wall of the abdominal aorta and occasionally from the common iliac artery. It runs behind the common iliac vein to the tip of the tail. In addition of giving off the lowest lumbar artery to each side, it gives rise usually at the level of the first sacral vertebra to the lateral caudal artery which supplies the upper half of the tail. In a very rare case, there was a very small branch which may be called the accessory medial caudal artery (A d a chi).

\section{Literature}

1. A d a ch i, B.: Das Arteriensystem der Japaner. Bd. II, Kyoto, 1928.

2. - On the abnormalities of the A. circumflexa femoris medialis. Tokyo Igk. Z., 10, 540, (1896), (Japanese).

3. : The A. obturatoria of the Japanese. Tokyo Iji-Shinshi, 2572, (1908), (Japanese).

4. As o, M.: On the blood vessels of trank in Japanese fetus. Part II. The Arterial system. Kaibo. Z., 5, 41, (1932), (Japanese).

5. A u burtin, G.: Die beiden Arteriae circumflexae femoris des Menschen. Anat. Anz., 27, 247, (1905).

6. Bang, F.B.: Observation on limb arteries of the wooly monkey. Anat. Rec., 66, 387, (1936).

7. Bluntschli, H: Die Arteria femoralis und ihre Äste bei den niederen catarrhinen Affen. Morph. Jahrb., 36, 276, (1906).

8. - Varietäten der Arteria profunda femoris und der Arteria circumflexa femoris medialis des Menschen. Morph. Jahrb., 7, 142, (1908).

9. Glid de n, E. M.: Arteries of the chimpanzee. Amer. Jour. Anat., 58, 502, (1936).

10. Hochstetter, F.: Über den Ursprung der Arteria caudalis beim Orang und beim Kaninchen nebst Bemerkungen über sogenante "Gefässwurzelwandlung ". Anat. Hefte, 43, 17, (1911).

11. - Über die ursprungliche Hauptschlagader der hinteren Gliedmasse des Menschen und der Säugethire, nebst Bemerkungen über Entwicklung Endaste der Aorta abdominalis. Morph. Jahrb., 16, 300, (1890).

12. Hoshia i, M.: On the pelvic artery of Japanese fetus. Kaibo. Z., 11, 61, (1938), (Japanese).

13. I m a i, S.: On the blood vessels of pelvis of the female macaque. Tokyo Igk. Z., 51, 642, (1937), (Japanese).

14. Kato, S.: Arterial anastomosis in the pudendal region. Tokyo Igk. Z., 47, 2000, (1933), (Japanese).

15. Koono, M.: Arteries on the gluteal region of Japanese. Kaibo. Z., 2, 631, 
(1929), (Japanese).

16. Kug it a, S.: On the deep epigastric artery of Japanese. Kyudai-Iho., 5, 46, (1931), (Japanese).

17. L i n e b a ck, P.: Anatomy of the rhesus monkey. (edited by Hartman \& Straus), Chapt. XII, New York, 1961.

18. Manners-Smith: The limb arteries of primates. Jour. Anat. \& Physiol., 46, 95, (1912).

19. Mizutani, A.: Arteries of the lower leg of Macacus cyclopsis. Fol. Anat. Japo. 34, 615, (1960).

20. Ohara, H.: Artery of the penis of Japanese fetus. Keio Igk., 24, 499, (1944), (Japanese).

21. O k a m oto, M.: Anatomical studies on perineum. (Part II. On blood vessels of perineum). Kagoshima Igk. Z., 11, 623, (1959), (Japanese).

22. Parsons, F.G.: On the blood vessels of mammals in relation to those of man. Lancet, 1, 651, (1902).

23. Po pow sky, T.: Das Arteriensystem der unter Extremitäten bei den Primaten. Anat. Anz., 10, 55, (1894).

24. - Phylogenesis des Arteriensystem der untern Extremitäten bei den Primaten. Anat. Anz., 8, 657, (1893).

25. Shimada, W.: On the pelvic limb artery of Japanese fetus. (Part I. Artery on the pelvic region). Keio Igk., 24, 759, (1944), (Japanese).

26. Thiele, W.: Über das Arteriensystem von Simia innus. Arch. f. Anat. \& Physiol. Wiss. Med., 19, 419, (1852).

27. Thomson, A.: Origin of the internal circumflex from the deep epigastric artery. Jour. Anat. \& Physiol., 17, 379, (1883).

28. Tsukamoto, N.: On the ramification of the pelvic artery of the Japanese. Kaibo. Z., 2, 830, (1929), (Japanese).

29. T u, C.: A. femoralis and its branches in Macacus cyclopsis. Acta med. Nagasaki, 7, 87, (1963).

30. Usui, M.: On the blood vessels of the pelvic and pudendal regions of male macaque. Tokyo Igk. Z., 50, 1225, (1936), (Japanese).

31. Vonwiller, P.: Eine seltene Varietät der Arteria iliaca communis sinistra. Anat. Anz., 10, 155, (1917).

32. Yasukawa, S.: Anatomical studies on the pelvic arteries of the Japanese, especially on the branch-types of a. iliaca interna. Tokyo Jikei Gyoseki, 12, 1, (1955), (Japanese).

33. Young, A.H.: Abnormalities of the middle sacral artery and their morphological significance. Jour. Anat. \& Physiol., 31, 169, (1887).

34. Zuckerkandl, E.: Zur Anatomie von Chiromys madagascrarensis, Denkschr. d. Kais. Akad. in Wien, 68, 89, (1899).

35. - Zur Anatomie und Entwicklungsgeschichte der Arterien des Unterschenkels und Fusses. Anat. Hefte, 5, 207, (1895). 